\title{
1245 高精度四面体要素を用いたフリーメッシュ法の前十字靭带大変形解析
}

\author{
Application of free mesh method using accurate tetrahedral element \\ to large deformation problems of anterior cruciate ligament \\ ○内川隆 (東大院) 正 矢川元基 (東大院) \\ Takashi Uchikawa, The University of Tokyo, Hongo7-3-1, Bunkyo-ku, Tokyo \\ Genki Yagawa, The University of Tokyo
}

Key Words: large deformation, accurate tetrahedral element, ligament

\section{1. はじめに}

近年スポーツの専門性、商業化が強くなる一方でそれに伴 う怪我が問題になってきている。一般の人にとってスポーツ は現代社会の中では既になくてならない余暇となったが、そ の一方でスポーツによって怪我をした場合、その怪我によっ ては仕事を含めた日常生活に甚大な影響を及ぼしかねない。 また、プロスポーツ選手に至ってはその選手生命自体を妿か す怪我も少なくはない。その中でも膝勒帯は複雑で激しい運 動を支えるため、勒帯の断裂はスキーをはじめ、様々な競技 で重要な問題である。しかし、膝勒帯はその怪我の深刻さに もかかわらず、力学的には不明な点も依然として多く、勒帯 断裂の防止に効果的なシミュレーション(1)(2)に関してもほと んど行われていない。

勒带断裂を防止するには、まず脚部に負荷が加わったとき に勒帯にかかる応力分布を求めることが必要である。しかし、 従来の有限要素法を用いた場合、六面体要素を用いて解析を、 行おうとすると精度は高いが、骨や勒帯など複雑な形状をし たものに対して要素生成自体ができず、また、解析の精度が 著しく低下してしまうような大変形をした場合にはリメッ シングをすることはできない。Voxel Mesh を用いた場合には 今度は表面が粗くなり、生体に忠実に要素生成をすることが できない。また、四面体一次要素を用いて解析を行おうとす ればほぼすべてのものに対して要素生成はできるが、解析の 精度が低いという問題があった。そこで、本研究ではリメッ シングと整合性の良い節点ベース有限要素法であるフリー メッシュ法のシステム (Free Mesh Method:FMM) ${ }^{(3)(4)(5)(6)} に$ 回転自由度を有する高精度四面体要素 ${ }^{(7)}$ を用いることによ り、骨や勒帯のような複雑な形状のものに対しても要素を生 成し、かつ精度の高い解析をできるようにする。

\section{2. 解析方法}

複雑な曲面形状を多数含む膝勒帯の数值解析においては、 従来の機械部品の数値解析のように CAD(Computer Assisted Design)などを用いて解析対象をモデル化することは困難で ある。したがって、解析対象の形状を正確に把握し、モデル 化するためには、解析対象そのものを直接入力データとする ことが不可欠である。これまでにも、眼球を凍結させ、複数 の断面形状の写真を撮り、それを直接解析モデルとして用い た研究 ${ }^{(8)}$ も行われている。本研究では、医療の分野で人体 内部の様子を知るために用いられている MRI(Magnetic Resonance Image)によって膝勒帯の断面画像を撮影し、その 断面画像を用いた直接的な形状モデリングを行う。一方态力 解析においては、フリーメッシュ法の解析システムを用いる。 FMM システムは、入力情報として、解析対象の形状および
境界条件のみを与え、解析内部において形状の要素分割を行 うシームレスな節点ベースの有限要素法であり、上記の膝勒 帯の形状およびそれに対する境界条件のデータのみで忘力 解析を行うことができ、またリメッシングや回転自由度を有 する高精度四面体要素との整合性もよい方法である。以下に 本研究における勒帯の応力解析の流れを示す。

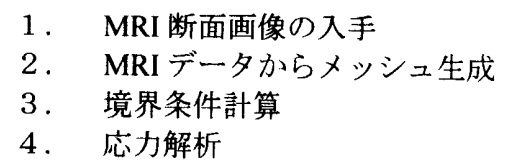

以下に本研究のアプローチの詳細を示す。

\section{（1） MRI 断面画像の入手}

Fig.1 (a)は入手した MRI 断面画像で、サンプルは著者（男 性 : 24 歳）の右膝である。画像は脚に垂直な断面を $4 \mathrm{~mm}$ 間 隔で 30 枚程度撮影した。Fig.1 (b)は Fig.1 (a)から抽出した大 腿骨である。

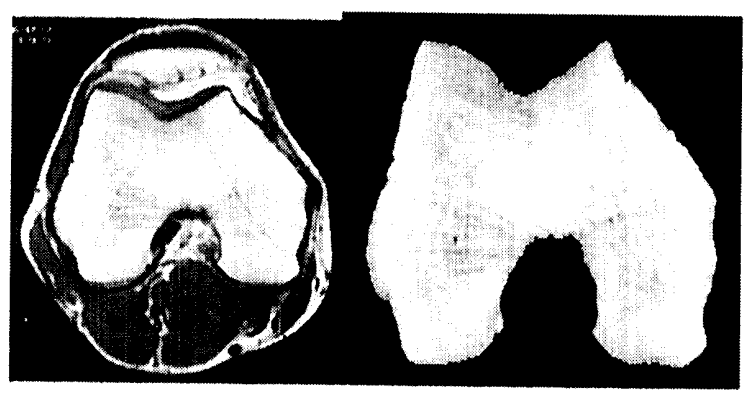

(a)

(b)

Fig.1 Cross section of knee

\section{（2） MRI データからメッシュ生成}

まず、撮影した MRI 断面画像から、勒帯と骨の部分を領 域成長法により別々に抽出する。勒帯に関しては前十字勒帯 を抽出し、骨に関しては、大腿骨と頸骨を抽出する。次に、 抽出した画像の軸を揃え2次元データを重ね合わせることに より 3 次元データを作成する。できた 3 次元データの表面を スムージングし、三角形状のパッチで表面を定義し、メッシ 工生成を行う。Fig.2 は得られた MRI 断面画像から大腿骨を 抽出して作った 3 次元データにスムージングをして作った大 腿骨と頸骨の先端部分である。 


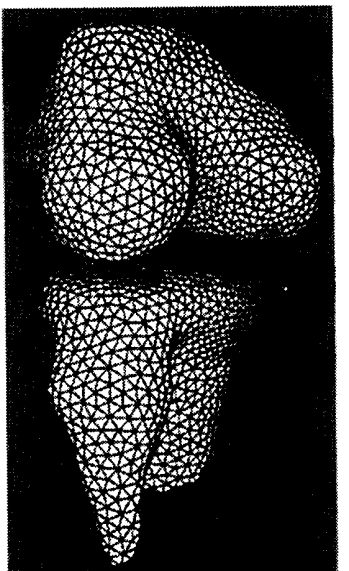

Fig.2 3D meshl of knee

\section{（3）境界条件計算}

解析する具体的な条件はスキーにおけるファント・フット 状態（急激にお尻が膝より下がってしまう状態）を想定して いるが、その状態は膝が可能域内で短時間で屈曲することと ほぼ等価であるため、膝が屈曲するための境界条件 ${ }^{(9)}$ を計算 した。

骨は勒帯と比べてた場合、その変形量は無視できるため、 剛体として扱い、よって Fig.2 の骨の勒帯に与える境界条件 の計算のみに用いた。

\section{（4）応力解析}

上記のように計算した境界条件を勒帯に与えて解析を行 う。靸帯の応力ーひずみ特性は厳密には非線形性 ${ }^{(10)}$ を示すが、 おおよそ線形であるとみなし、線形弾性体大変形理論 ${ }^{(11)}$ を用 いて解析を行う。

解析に用いる回転自由度を有する高精度要素四面体要素 は Fig.3のような 1 節点に 6 自由度を持つ 4 節点四面体要素 で、ねじりや曲げにおいて 10 節点四面体 2 次要素と同等の 精度が出ることが確認されている(7)。
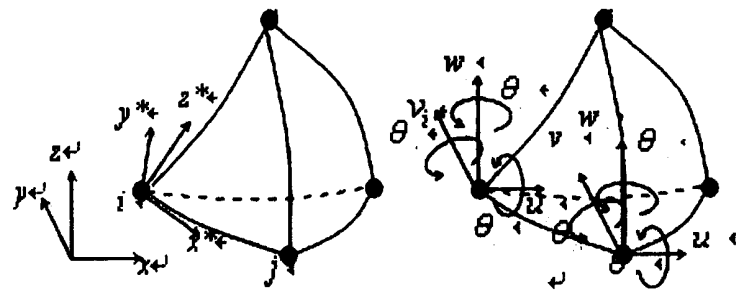

Fg.3 TET element Including drilling degrees of freedom

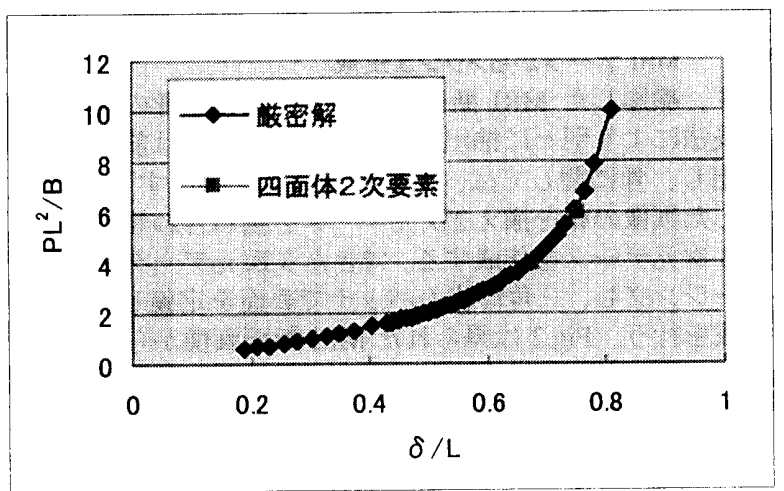

Fig.4 Load vs. deformation

図 4 は、片持ち梁の変位と荷重の厳密解 ${ }^{(12)}$ と、四面体 2 次要素による解析結果を示している。P が荷重、L が梁の長
さ、 $\delta$ が荷重方向の変位量、B=EI、I は断面 2 次モーメント である。四面体高精度要素における解析結果はまだ示せては いないが、微小変形の分野では四面体 2 次要素と同程度の結 果が得られていることと、図 4 から、高精度四面体要素を大 変形に用いた場合にも厳密解に近い值が出ると予想される。 この結果は講演時に示す。

\section{3. 終わりに}

本研究では、膝などの生体を対象としたシミュレーション を計算する際のアプローチを中心に説明してきた。現時点で は、モデリングに関しては骨と勒帯のメッシュ作成まで完了 し、解析に関しては回転自由度を有する高精度四面体要素を 用いた弾性体大変形コードを開発中である。講演時にはこの アプローチを用いた解析結果を示寸予定である。

\section{謝辞}

本研究の一部は、東京大学生産技術研究所における「戦略 的基盤ソフトウェアの開発」プロジェクトの支援を受けた。 MRI 画像の撮影においては東京都教職員救済組合青山病院 に多大な支援を頂いた。また同病院の山岸恒雄氏には膝勒帯 に関しての有益な議論を頂いた。ここに記して感謝の意を示 す。

\section{参考文献}

1) 廣川俊二, 鶴野玲治 : 膝前十字勒帯の三次元変形と応力 分布(線維束で補強された超弾性体の構成式と有限要素 モデル)，日本機械学会論文集(C編), 64 巻 622 号, pp, 1998

2 ) 廣川俊二, 鶴野玲治 : 有限要素法による膝十字勒带の三 次元変形と応力分布(第 2 報, モデル解析と可視化シミ ユレーションの結果), 日本機械学会論文集( $\mathrm{C}$ 編), 65 巻 632 号, pp, 1999

3) G.Yagawa, T.Yamada : Free mesh method; A new mesh method, Int.J.Comput.Mesh, 18, pp383-386, 1996

4) GYagawa, T.Furukawa : Recent developments of free mesh method, Int. J.Numer. Meth. Engng, 47, pp 1419-1443, 2000

5 ）稲葉正和, 藤澤智光, 矢川元基 : 階層型バケットと包装 法による並列メッシュ生成法，日本機械学会 2002 年度 年次大会 講演論文集, Vol. I, 37-38, 2000

6 ）渡部修, 瀬川冬樹 : フリーメッシュ法の弾塑性大変形問 題への適用, 日本機械学会論文集(A編), 65 巻 630 号, pp268-276, 1999

7 ）松原仁: 回転自由度を有する高精度四面体要素の開発及 びフリーメッシュ法への適用, 琉球大学大学院理工学系 研究科環境建設工学専攻修士論文, 2003

8) Z.G.Sun, A.Makinouchi : Improved 3D FEM program for simulating the retina detachment operation on an eyeball, RIKEN SYMPOSIUM Computational Biomechanics, pp45-55, 2002

9 ) P.Otte, K-F.Schlegel : Buecherei des Orthopaeden Band 47 Funktionelle Anatomie der Gelenke, Ferdinand Enke Verlag Stuttgart, 1980

10 ）林紘三郎：バイオメカニクス，コロナ社, 2000

11 ）久田俊明, 野口裕久: 非線形有限要素法の基礎と応用, 丸善, 1995

12 ) K. E. Bisshop and D.C. Drucker : Large Deflection of Contilever Beams, Quarterly of Applied Mathematics, vol3, no.3, 1945, p272-275 